\title{
Marita Hietasaari
}

\section{Metalepsis kerrontastrategiana Lars Sundin historiallisissa romaaneissa}

\author{
Spänn de här stolpskorna på fötterna, läsare! Nu skall vi upp i stolpen därborta \\ och tjuvlyssna på vad siklaxborna kan tänkas ha att säga varann i telefon en \\ lördagskväll i augusti 1924 [- - ]. \\ VAD GÖR NI DÄROPP I TELEFONSTOLPIN! \\ En gäll och ilsken röst nedifrån landsvägen. Och jag, berättaren, blir så försk- \\ räckt att jag handlöst ramlar ner från stolpen. (CA, 282, 284-285.)
}

Kiinnitäpä nämä tolppakengät jalkaan, lukija! Nyt kiipeämme tuohon pylvääseen salakuuntelemaan mitä sanottavaa Siklaxin asukkailla mahtaa olla toisilleen puhelimitse lauantai-iltana elokuussa 1924 [- - ]. MITÄS TE SIÄLLÄ PUHELINTOLPAS TEETTE!

Kimakka ja äkäinen ääni alhaalta maantieltä. Ja minä, kertoja, säikähdän niin että putoan päistikkaa pylväästä. (CAV, 277, 279.)

Lars Sundin historiallisten romaanien kertoja liikkuu esteettä aikatasolta toiselle ja paikasta toiseen. Edellisessä kohtauksessa kertojan kera maahan tömähtää myös lukija, jonka kertoja on pyytänyt mukaansa tutkimusretkelle menneisyyteen. Kertojan avoin esiin tuleminen, tapahtumiin puuttuminen ja lukijan puhutteleminen rikkovat mimeettisen illuusion, johon realistisessa kerronnassa perinteisesti pyritään.

Lars Sundin Siklax-trilogian muodostavat romaanit Colorado Avenue 1991 (suom. 1992), Lanthandlerskans son 1997 (suom. Puodinpitäjän poika 1998) ja Eriks bok 2003 (suom. Erikin kirja 2004). Sarja kuvaa Hanna Näsin ja hänen jälkeläistensä vaiheita 1800-luvun lopulta aina sotien jälkeiseen aikaan. Tapahtumat sijoittuvat kuvitteelliseen Siklaxin kuntaan Etelä-Pohjanmaalle. Kertojana teoksissa toimii historioitsijan lailla sukunsa vaiheita tutkiva Carl-Johan Holm. Jokaisessa osassa on kirjoittamisajankohtaan sijoittuva kehyskertomus, josta käsin menneisyyttä tarkastellaan. Carl-Johanin omalaatuisiin tutkimusmenetelmiin kuuluu vierailla menneisyydessä sukulaisiaan tapaamassa ja aikalaisia haastattelemassa. Kertojan toimien seurauksena kehyskertomus ja sisäkertomus sekoittuvat. Kerrontatasojen sekoittuminen eli metalepsis kiinnittää lukijan huomion tapahtumista itse kerrontaan. Myös kertojan tapa pohtia avoimesti omaa kerrontaansa ja käyttämiään keinoja tuovat Sundin teoksiin metafiktiivisen tason. ${ }^{1}$ Postmoderni kirjallisuus onkin käyttänyt metafiktiota siinä määrin, että ne on usein samaistettu toisiinsa (Saariluoma 1992, 23-24). Sundin teoksista löytyy muitakin yleensä postmodernistisina pidettyjä piirteitä. ${ }^{2}$ Yksi leimallinen on ns. historiografinen metafiktio, jota Linda Hutcheon (1988, 4-5) käyttää kuvaamaan itserefleksiivisiä teoksia, jotka ovat sekä historiallisia että poliittisia. Sundin teokset korostavat 
historiankirjoittamisen vaikeutta: onko meidän mahdollista tietää mitään varmaa menneisyydestä? Mielenkiintoisen tutkimuskohteen Sundin romaaneista tekee myös niiden yhteiskuntakriittisyys, sillä teokset kommentoivat niin menneisyyden kuin kirjoittamisajankohdan tapahtumia. Kerrontatasojen sekoittaminen tuo eri aikakaudet keskusteluyhteyteen toistensa kanssa. Tarkastelen artikkelissani millä tavoin ja missä tehtävissä metalepsista on käytetty Sundin Siklax-trilogiassa. Selostan alkuun lyhyesti Gérard Genetten, Monika Fludernikin ja Marie-Laure Ryanin teorioita. Oma käsittelyni pohjautuu hyvin pitkälti Fludernikin tekemään jaotteluun. Keskityn erityisesti kertojan toimien seurauksena tapahtuvaan kerrontatasojen sekoittumiseen, mutta esittelen myös muita teoksissa esiintyviä metalepsiksen muotoja.

\section{Metalepsis: retoriikasta narratologiaan}

Metalepsista on tutkittu viime vuosina suhteellisen runsaasti. ${ }^{3}$ Keskustelun aloitti Gérard Genette (1990, 234-235), joka antoi alun perin retoriikassa käytetylle termille uuden merkityksen määrittelemällä sen ekstradiegeettisen kertojan tai yleisön siirtymiseksi diegeettiselle tasolle tai diegeettisen tason henkilöhahmon siirtymiseksi alemmalle tasolle (tai päinvastoin). Kyse on siis kerrontatasojen sekoittumisesta, jossa kahden maailman välinen raja ylitetään: "maailman jossa kerrotaan ja maailman josta kerrotaan" (Genette 1990, 236). Retoriikassa ${ }^{4}$ metalepsis tarkoittaa sanan tai ilmaisun korvaamista toisella. Tämä metonymian muoto kuvaa syyn tai alkutilanteen avulla seurausta tai seurauksen avulla syytä. (Genette 2004, 8-10.) José Ángel García Landan (2004) mielestä Genette on käsitettä muovatessaan tukeutunut liiaksi 1800-luvulla vaikuttaneen Pierre Fontanierin ${ }^{5}$ kirjoituksiin retoriikasta. García Landan mukaan Fontanier lisää retorisen metalepsiksen ominaisuuksiin täysin mielivaltaisesti kerrontatasojen ylittämistä koskevan piirteen. García Landa puhuukin mieluummin kehysten murtumisesta (la ruptura de marco).

Marie-Laure Ryan erottaa retorisen ja ontologisen metalepsiksen. ${ }^{6}$ Ryanin mukaan retorinen metalepsis sallii meidän vilahdukselta nähdä eri kerrontatasot, mutta sulkee aukon saman tien ja realistisuuden illuusio särkyy vain hetkeksi. Esimerkkinä Ryan mainitsee Denis Diderot'n teoksen Jacques le fataliste et son maître (1773, Jaakko fatalisti ja hänen isäntänsä 1992), jossa kertoja puhuttelee lukijaa ja pohtii, mitä tekisi henkilöhahmoilleen. Hän ei kuitenkaan puhu luomilleen hahmoille, koska nämä kuuluvat toiselle todellisuuden tasolle. Ontologisessa metalepsiksessa kaksi eri maailmaa, esimerkiksi (fiktion) todellinen ja kuvitteellinen tai normaali maailma ja unen maailma sekoittuvat. Suurin osa ontologista metalepsista koskevista esimerkeistä löytyy postmodernista kirjallisuudesta. (Ryan 2006, 206-207.) García Landan (2004) mielestä siirtymistä kerrontatasolta toiselle ei välttämättä tapahdu ollenkaan, vaan siirtymä voi tapahtua ontologisten tasojen välillä. Esimerkkinä hän mainitsee Marguerite 
Yourcenarin novellin Comment Wang-Fo fut sauvé (1938 "Kuinka Wang-Fo pelastui" $)$, jossa päähenkilö pelastautuu julmalta rangaistukselta maalaamansa taulun kautta. Genetten (2004, 94-96) mukaan kuva, jonka kertoja elävöittää osaksi tarinaansa, muodostaa yhden kerrontatason. ${ }^{8}$

Monika Fludernik yhdistää Genetten esimerkkien pohjalta tekemäänsä ryhmittelyyn ${ }^{9}$ vielä Ryanin jaottelun ontologiseen ja retoriseen metalepsikseen ja saa seuraavan tyypittelyn (2003, 389): 1. kirjoittajan/tekijän metalepsis (authorial metalepsis), 2. kertojan metalepsis (narratorial metalepsis) (ontologinen), 3. lukijan metalepsis (lectorial metalepsis) (ontologinen), 4. retorinen metalepsis (rhetorical metalepsis). Fludernik tuo analyysissaan esiin metalepsiksen historiallisen perspektiivin. Metalepsis ei ole pelkästään postmodernin kirjallisuuden käyttämä, vaan sitä on esiintynyt jo keskiaikaisessa kirjallisuudessa, mutta se on kehittynyt vuosisatojen kuluessa retorisesta tyylikeinosta yhä metafiktiivisempään suuntaan. (Fludernik 2003, 389-396.) Historiallisen näkemyksensä ansiosta jaottelu sopii hyvin Sundin teosten tarkasteluun, vaikka ei täysin katakaan kaikkia teoksissa käytettyjä metalepsiksen muotoja. Kuten Fludernik (2003, 389) huomauttaa ja omatkin esimerkkini tulevat osoittamaan, rajat eri tyyppien välillä ovat häilyvät.

\section{Kertoja astuu tarinaan}

Kertojan metalepsis (narratorial metalepsis) on postmodernin kirjallisuuden suosikki. Siinä kertoja kirjaimellisesti siirtyy sisäkertomukseen tai henkilöhahmo siirtyy toiselle, usein alemmalle tasolle. Tutkijoiden lempiesimerkki on ollut Woody Allenin ${ }^{10}$ novelli "Kugelmassin episodi" (1981) (ks. esim. McHale 1987, 123; Fludernik 2003, 384; Genette 2004, 30-31). Novellissa humanististen tieteiden professori kaipaa vaihtelua elämäänsä ja päättää turvautua taikuriin, joka siirtää hänet Gustave Flaubertin Rouva Bovaryn maailmaan. Kertoja viettelee turhautuneen Emma Bovaryn ja tuo tämän jopa käymään New Yorkissa. Kugelmassin vierailut teoksessa eivät jää huomaamatta (Allen 1981, 52): "'Kuka tämä henkilö on sivulla sata? Kalju juutalainen, joka suutelee madame Bovarya?"”, ihmettelivät koululaiset eri puolilla maata. Tarinan lopussa taikurin kone rikkoutuu ja Kugelmass ei pääsekään haluamaansa maailmaan, vaan Rothin Portnoyn taudin sijaan hän joutuu espanjan oppikirjaan:

Hän oli paiskautunut vanhaan oppikirjaan, Espanjan tukikurssiin, ja pinkoi henkensä edestä karussa, kivisessä maastossa, kun sana tener ("olla, omistaa") - iso ja karvainen epäsäännöllinen verbi - ravasi hänen kintereillään honteloilla koivillaan (Allen, 1981, 62).

Siklax-trilogiassa Carl-Johan on kaikkitietävä ja kaikkivaltias kertoja, jonka yhtenä kerrontastrategiana on sukeltaa osaksi kertomaansa maailmaa. Fludernik (2003, 384385) toteaa, että tämän tyylinen siirtyminen tasolta toiselle on ollut käytössä jo kauan, 
tarkoitus vain on muuttunut: mimesiksen lisäämisen sijaan postmoderni kirjallisuus pyrkii rikkomaan toden illuusion. Perinteisessä tarkoituksessa kertojan metalepsista on käytetty runsaasti muun muassa historiallisissa romaaneissa. Zacharias Topeliuksen teoksesta Fältskärns berättelser (1851-1866, Välskärin kertomuksia 1888) löytyy lukuisia esimerkkejä tämän kaltaisista siirtymistä: ”I stället att hålla honom [Erik Ljung] sällskap, förflytta vi oss till den drottning Lovisa Ulrikas förmak" (Topelius 1923, 107), "Sen sijaan, että jäisimme hänelle seuraa pitämään, siirrymme me kuningatar Loviisa Ulriikan vierashuoneeseen" (Topelius 1998, 68). Lanthandlerskans son -teoksessa siirtymä on vähän modernimpi:

Men nu, Otto, lämnar vi Hanna och hennes dotterson åt deras öde, åtminstone för en stund, och snabbspolar historiens band nästan ett år framåt. [- - ] Nu tar berättelsen ett nytt raskt språng, icke i tiden men väl i rummet: vi hamnar strax i en sjukhuskorridor. (LS, 272, 273.)

Mutta nyt, Otto, jätämme Hannan ja hänen tyttärenpoikansa kohtalon huomaan, ainakin hetkeksi, ja pikakelaamme historian nauhaa melkein vuoden eteenpäin. [- - ] Nyt kertomus ottaa uuden reippaan loikan, ei ajassa mutta kylläkin tilassa: me päädymme oitis sairaalan käytävään. (PP, 293.)

Edellisessä esimerkissä on kyse siirtymisestä yhdestä kohtauksesta tai tilanteesta toiseen: toiselle näyttämölle, toisten henkilöiden pariin. ${ }^{11}$ Fludernikin neljäs metalepsiksen tyyppi liittyy oleellisesti edellä mainittuun. Retorinen metalepsis leikittelee tarinan ja kerronnan ajoilla. Kertoja täyttää tarinan suvantokohdan esimerkiksi palauttamalla lukijan taaksepäin tarinassa tai informoimalla häntä jostakin asiasta, ikään kuin kertominen olisi yhtäaikaista tarinan tapahtumien kanssa. ${ }^{12}$ (Fludernik 2003, 387; Genette 1990, 235.) "Medan Otto sover och jag arbetar skall jag berätta om min farfar" (LS, 319), "Sillä välin kun Otto nukkuu ja itse teen töitä minä kerron isäni isästä" (PP, 344). William Nellesillä ja Fludernikilla on molemmilla hiukan vaikeuksia pitää edellisen kaltaista tapausta metalepsiksena. Fludernik päätyy siihen, että kerrontatasot sekoittuvat, koska tapahtumien samanaikaisuus pakottaa kertojan siirtymään kertomaansa maailmaan. Nellesin mielestä kyse ei ole siirtymisestä tasolta toiselle, vaan kertoja ikään kuin jakaa hetkellisesti saman tason sisäkertomuksen henkilöhahmon kanssa. Hän pitää esimerkkiä eräänlaisena metalepsiksen perusmuotona. (Nelles 1997, 153-154; Fludernik 2003, 387.)

Toisinaan tapahtumien kiivas eteneminen pakottaa kertojan seisauttamaan toiminnan. Jo Laurence Sternen teoksessa The Life and Opinions of Tristram Shandy, gentleman (1759-1767, Tristram Shandy: elämä ja mielipiteet 1998) on kohtauksia, joissa kertoja pysäyttää toiminnan ehtiäkseen saattaa tapahtumat kaikkialla samalle tasolle (Genette 1990, 235; Fludernik 2003, 387). Seuraavassa kohtauksessa kertoja on siirtynyt menneisyyteen sisäkertomuksen tasolle, minkä lisäksi hän on "som den gud [- - ] stannat tidens pendel" (CA, 170), "omassa jumalan asemassaan pysäyttänyt ajan heilurin" (CAV, 
166) haastatellakseen puodin penkillä istuvia ukkoja. Kertoja on saanut todistaa kohtausta, jossa Kunnanmiehen vanhin poika Erik tulee Hannan kauppapuotiin kyselemään Ottoa. Poikien ystävyys on hänelle yllätys:

Vad skall månne detta betyda? [- -] Berättaren vänder sig till karlarna på bänken: tala nu om hur jag skall uttolka detta! [- - Karlarna syns ovilliga att tala om detta. Detaljer, ge mig detaljer! kräver berättaren. (CA, 169-170.)

Mitä tämä nyt mahtaa tarkoittaa? [- -] Kertoja kääntyy penkillä istuvien miesten puoleen: Sanokaa nyt miten minun on tämä tulkittava! [- - ] Miehet eivät näytä oikein halukkailta puhumaan tästä. Tarkemmin, kertokaa tarkemmin! kertoja vaatii. (CAV, 165-166.)

Kertoja ei suinkaan informoi lukijaa vaan pysäyttää ajan saadakseen tietoja. Mielenkiintoista tässä nurinkurisessa kohtauksessa on myös se, että miehet puhuvat Erikistä menneessä aikamuodossa ja heidän huomautuksistaan käy ilmi, että he tietävät Erikin tulevan kohtalon. Keskustelu käydään ikään kuin ajattomassa tilassa - onhan kertoja seisahduttanut ajan kulun. Nellesin $(1997,154)$ näkemys yhteisen tason jakamisesta vaikuttaa edellisen esimerkin valossa osuvalta. Kohtauksessa yhdistyvät Fludernikin jaottelun toinen ja neljäs tyyppi eli kertojan metalepsis ja retorinen metalepsis, sillä kertoja on myös kirjaimellisesti miesten luona puodissa, ja kun hän innostuu utelemaan Hannan ja Kunnanmiehen ystävyydestä, hän saa äkkilähdön: "Laga dig iväg, berättare! Int vill nåin ha dig snokandes och rotandes här!” (CA, 173), ”Alas mennä siittä, kertoja! Ei sua kaivata tänne nuuskimahan!" (CAV, 169.)

Teoksessa Lanthandlerskans son kertoja kohtaa vastarintaa paitsi Otolta kehyskertomuksessa myös itse tarinan henkilöiltä. Kertoja seuraa, kuinka Hanna sulkee kauppapuotinsa samalla pohtien viimeaikaisia tapahtumia: poliisi epäilee Oton sotkeutuneen murhaan, ja Otto on paennut. Lisäksi Hannan tyttären Idan miehen Gustavin epäillään olleen mukana tohtori Öistin kyydityksessä ja aiheuttaneen tämän kuoleman. Hanna sytyttää savukkeen, ja kertoja pyytää "den tålmodiga läsaren om diskretion" (LS, 264), "kärsivälliseltä lukijalta hienotunteisuutta" (PP, 284): sallittakoon Hannalle tämä nautinto, onhan Jumala kovin koetellut häntä. Tällöin Hanna saa kertojasta tarpeekseen:

- Ingalunda är det nu Gud som prövar mig! avbryter Hanna bryskt.

- Vad säger du?

- Nå, he är ju du, berättare, som har ställt till att allting åp det här gruvliga vise, så är he! Det är ju dina historier och påfund som vi gåtar lid och pinas av.

Du drar olöckorna över oss, he gör du, och int ska du kom och skyll åp Herren Gud int!

- Ingalunda är det nu mitt fel. Jag är bara ett redskap, en förmedlare av berättelsen, historiens springpojke, försvarar jag mig. (LS 264.)

- Ei se kyl Jumala ole joka täs mua koetteloo! Hanna keskeyttää töykeästi.

- Mitä tarkoitat?

- No, sinähän se olet, kertoja, joka olet järjestäny kaiken näin kauhialla tavalla, 
niin on asia! Sun tarinoittes ja sepitystes takia me täs jourumma kärsimähän ja tuskittelemahan. Sinä se verät onnettomuuret meirän päälle, sinä justihinsa, eikä sun pirä tulla Herraa Jumalaa syyttelemähän!

- Eihän se minun vikani ole. Minähän olen pelkkä työkalu, kertomuksen välittäjä, tarinan juoksupoika, minä puolustelen itseäni. (PP, 284.)

Lukijaa ei herätellä pelkästään siirtymällä kerrontatasolta toiselle, vaan henkilöhahmo vaatii luojansa tilille kohtalostaan. Teos tuo korostuneesti esiin kirjallisuuden konstruktiivisen luonteen ja murtaa realistisuuden illuusion. Vaikka kertoja yrittää todistella olevansa vain "en förmedlare av berättelsen", "kertomuksen välittäjä", lukija on jo saanut todeta hänen olevan tarinan suhteen kaikkivaltias. Yksi kertojan strategioista on vähätellä tietämystään ja mahdollisuuksiaan vaikuttaa tapahtumiin. Jonathan Cullerin (2004, 30-31) mukaan kerrontaa avoimesti kontrolloiva kertoja voi kiistää tietävänsä aivan kaikkea, jolloin säilyy jonkinlainen realismin illuusio. Sundin kertoja korostaa tietämättömyyttään kuitenkin niin voimakkaasti, että vaikutus on päinvastainen. Hannaan eivät kertojan puolustelut tehoa, ja hän ajaa tämän luudalla jahdaten ulos puodistaan:

Måsta du la Otto vår till en poliskund! Va he nödvändit ti få Ida så olöckli så hon int vet var hon ska ta iland, unga kvinnan är hon ännu men du har ställt så hon blir en gammal kälg före sin tid! [- -] Du sku nog ha kunna gev oss ett bättre liv än det här, men int. (LS 265.)

Pitikö sun tehrä meirän Otosta poliisikundi. Oliko se välttämätöntä tehrä Idasta niin onneton nottei se tiärä mihin kääntyä, nuari nainen se viälä on ja nyt sinä olet järjestäny niin jotta siitä tuloo vanaha akka ennen aikojansa. [- - Olisit kyllä voinu antaa meille paremman elämän ku tämä, mutta ei. (PP, 285.)

Sundin teosten kertoja ei korosta vain luomansa maailman fiktiivisyyttä vaan toteaa olevansa itsekin fiktiota ja pysyvänsä hengissä vain kertomalla. Seuraavassa otteessa kertoja pohtii myös oman kertomuksensa mielekkyyttä:

Belägringen av Sarajevo kan jag inte häva med min berättelse. Vår för miljön menliga livsstil kan jag inte ändra. Så varför hålla på? Därför att jag inte kommer undan, jag är själv fiktion. Jag berättar mig själv. Endast så hålls jag vid liv. (LS, 373.)

Sarajevon piiritystä en kykene kertomuksellani lopettamaan. Meidän ympäristöllemme haitallista elämäntapaamme en pysty muuttamaan. Joten miksi jatkaa? Siksi etten muuta voi, olen itsekin fiktiota. Minä kerron oman itseni. Vain siten pysyn elossa. (PP, 402.)

Brian McHale $(1987,123)$ toteaa, että henkilöhahmon tietoisuus omasta fiktiivisyydestään on usein viittaus determinismiin ja erityisesti kuoleman väistämättömyyteen. ${ }^{13}$ Genetten $(1990,236)$ mukaan hämmentävintä on, että metalepsis saa lukijan pohtimaan, onko hänkin ehkä vain osa jotain kertomusta ja kuinka todellista hänen oma 
elämänsä on (ks. myös McHale 1987, 130; Genette 2004, 155). Nellesin (1997, 156157) mielestä sisäkertomuksen käyttö yleensä saa aikaan saman vaikutuksen tapahtui kerrontatasojen ylitystä tai ei. Olen eri mieltä Nellesin kanssa, koska kehyskertomus on vanha konventio ja lukijat ovat tottuneet kertomusten hierarkkiseen rakenteeseen. Sitä vastoin kertomuksen hierarkkisten suhteiden rikkominen (tekijä -> teksti -> kertoja -> henkilöt) havahduttaa outoudellaan, esimerkiksi jos henkilöhahmot alkavat puhutella kertojaa tai kertoja on tietoinen omasta fiktiivisyydestään (Tammi 1992, 12).

Sundin teoksissa sekä kertoja että henkilöhahmot kiinnittävät lukijan huomion esitystapaan. Itserefleksiivisyys on historiografisen metafiktion peruspiirre, mutta pelkästään oman kerrontansa kommentointiin keskittyviä metafiktiivisiä teoksia Hutcheon ei pidä postmodernismiin kuuluvina (Hutcheon 1988, 40). ${ }^{14}$ Itsetietoista metafiktiota on kritisoinut myös Mika Hallila (2004, 216): ”Tyhjänpäiväinen romaanin keinotekoisuuden korostaminen voi muodostua paljon realistisen romaanin konventioitakin läpinäkyvämmäksi esittämisen konventioksi.” Hallila $(2004,218)$ tähdentääkin ironian merkitystä itsereflektiossa ja mainitsee esimerkkinä Sternen romaanin Tristram Shandy. Sundin teokset täyttävät Hutcheonin historiografisen metafiktion määritelmän muiltakin osin, sillä ne ovat sekä historiallisia että poliittisesti kantaaottavia, kuten esimerkkini osoittavat.

\section{Tule mukaan, lukija!}

Kolmas metalepsiksen tyyppi on yleisön siirtyminen sisäkertomukseen tai sisäkertomuksen henkilöhahmon siirtyminen ylemmälle tasolle. Kyseessä voi olla myös toisen persoonan kerronta, kuten Italo Calvinon romaanissa Se una notte d'inverno un viaggiatore (1979, Jos talviyönä matkamies 1983), jossa yksikön toisessa puhuteltu lukija paljastuu sittemmin yhdeksi henkilöhahmoista. Sterne käyttää teoksessaan Tristram Shandy metalepsista rikkomaan mimeettisen illuusion: Tristram muun muassa pyytää lukijaa sulkemaan oven ja auttamaan hänen isänsä takaisin vuoteeseen. (Genette 1990, 234.) McHale $(1987,223)$ huomauttaa, että fiktiossa, jossa puhutellaan lukijaa, sinäpronomini on häilyvä: sinä on muuttuja, joka vaihtuu jokaisen lukijan myötä. Tristram Shandy -teoksen kertoja leikittelee tällä ja puhuttelee lukijaansa miehenä, naisena, yksikössä, monikossa, kriitikkona jne.:

Kuinka te saatoitte, hyvä rouva, lukea edellisen luvun niin huolimattomasti? (Sterne 1998, 60.)

Hyvä herra, sallikaa minun kiinnittää huomionne hetkeksi tähän kuvaukseen (Sterne 1998, 101).

Sundin kertoja kääntyy usein lukijan puoleen ja kutsuu tämän mukaansa. Amatöörivalokuvaajana toimineen opettaja Johanssonin lasinegatiivit huutokaupattiin tämän kuo- 
leman jälkeen. Lasit osti Eskil Holm rakentaakseen niistä kasvihuoneen: "Med hjälp av borste och bensin skurade han bort trettio år av Siklaxnejdens historia från sina nyförvärvade glasplåtar" (CA, 206), ”Harjalla ja bensiinillä hän kuurasi pois kolmekymmentä vuotta Siklaxin seudun historiaa vasta hankkimistaan lasilevyistä” (CAV, 201). Lasinegatiiveja oli tuhansia, eikä niiden täydellinen puhdistaminen ollut mahdollista, niinpä kasvihuoneen seiniin jäi osia kuvista. Kertoja kutsuu lukijan tutustumaan tähän erikoislaatuiseen kotiseutuarkistoon:

Kom! Vi skall titta på lärar Johanssons fotografier.[- -] På växthusets långvägg, nära marken, sitter ett negativ som är värt närmare granskning. Berättaren måste dock be den tålmodige läsaren ställa sig på huvudet - sådär ja! Glaset har nämligen kittats fast up och ned. (CA, 206-207.)

Tule! Mennään katsomaan opettaja Johanssonin valokuvia. [- - ] Kasvihuoneen pitkällä seinällä lattianrajassa on negatiivi joka ansaitsee tarkempaa tutkimista. Kertojan on kuitenkin pakko pyytää että kärsivällinen lukija seisoisi päällään — kas noin! Lasi on nimittäin kitattu ylösalaisin. (CAV, 201-202.)

Kertoja turvautuu historiankirjoituksessaan huomiota herättävän paljon dokumentaariseen aineistoon: päiväkirjaotteisiin, sanomalehtiin, tutkintaraportteihin, kirjeisiin, valokuviin jne. Menneitä tapahtumia esittävistä lasinegatiiveista on rakennettu uusi kokonaisuus. Analogia perinteiseen tapaan kirjoittaa historiaa on ilmeinen: kuinka ihmeessä muodostaa uskottava kokonaisuus menneisyyden jälkeensä jättämistä fragmenteista? Kathy Saranpan (1998, 274-275) mielestä kasvihuone ja lasinegatiivit ilmentävätkin sitä, kuinka perinteinen historiakirjoitus joutuu aina turvautumaan kaunokirjallisuuden menetelmiin.

Fludernik $(2003,394)$ toteaa, että sinä-pronomini voi viitata teoksen ekstradiegeettisen tason yleisöön tai teoksen lukijaan ja että jokainen tapaus on tarkasteltava erikseen; kyse saattaa olla vain metaforisesta kerrontatason ylittämisestä. Toisin sanoen tarkoituksena on saada lukija uppoutumaan tarinan maailmaan. Klassisessa historiallisessa romaanissa lukijan puhuttelu oli normaali käytäntö, jolla tekijä loi suhteen lukijoihinsa: Fältskärns berättelser -teoksessa Topelius käyttää usein fraaseja "den vänlige läsaren" ,"ystävällinen lukija” ja "den gunstige läsaren", ”suosiollinen lukija”. Sen sijaan Sundin teoksissa lukijan puhutteleminen useimmiten rikkoo realistisen illuusion, sillä kertoja pyytää Tristram Shandyn tavoin lukijaa tekemään konkreettisia asioita: kiipeämään puhelinpylvääseen tai seisomaan päällään. Ei ihme, että kertoja puhuttelee lukijaa usein fraasilla "den tålmodige läsaren", "kärsivällinen lukija”. McHalen (1987, 224) mukaan erityisesti postmodernisteilla sinä-pronomini on kuin kutsu lukijalle astua sisään teoksen maailmaan ja ylittää ontologinen raja fiktion ja todellisuuden välillä. Lukijan on tietysti mahdotonta siirtyä reaalimaailmasta fiktion maailmaan. Ero metaforisen ja "todellisen" kerrontatasojen ylittämisen välillä onkin joskus häviävän pieni, toteaa Fludernik $(2003,396)$. 
Teoksessa Eriks bok Siklaxin vainajat väittelevät kertojan kanssa sota-ajan tapahtumista kirkkoherra Taxellin johdolla ja moittivat kertojaa paitsi historian tulkinnasta myös hänen tavastaan kertoa. Kerronnallisten tasojen lisäksi rikkoutuu myös raja elävien ja kuolleiden maailmojen välillä. Ryanin erottelun mukaan kyseessä on siis ontologinen metalepsis, kahden eri maailman sekoittuminen. Teoksen aloittavat vainajat, jotka puhuttelevat lukijaa:

Välkommen. Vi har väntat på dig. Vi är de döda från Siklax. Stig på bara! Träd in i salen på Smedsas! Du behöver inte vara rädd. Döda är vi förvisso, men ingalunda farliga. Vi försäkrar att inga iskalla, osynliga händer kommer att slutas om din hals. [- - ]

Men stig på för all del! [- -] Slå dig ned i gungstolen borta vid fönstret! (EB, 5.)

Tervetuloa. Me olemme odottaneet sinua. Me olemme Siklaxin vainajia. Astu sisään vain! Käy peremmälle Smedsasin saliin! Ei sinun tarvitse pelätä. Toki olemme vainajia, mutta emme yhtään vaarallisia. Me vakuutamme, etteivät hyiset näkymättömät kädet tule kouristumaan kurkkusi ympärille. [- - ]

Mutta käy nyt kaikin mokomin sisään! [- - Istu siihen keinutuoliin ikkunan ääreen! (EK, 7.)

Vainajat esittelevät lukijalle salin seinällä olevat Smedsin suvun henkilöt, joista tarina tulee kertomaan. Sitten he pyytävät Carl-Johania astumaan esiin. Sitä ennen pieni varoituksen sana lukijalle: "[H]an är en pratmakare och inpiskad lögnare” (EB, 9), "[H]än on suupaltti ja piintynyt valehtelija" (EK, 10). Lukijan ei tarvitse kuitenkaan olla huolissaan, koska vainajat aikovat pitää huolen siitä, ettei moraalia ja säädyllisyyttä, saati isänmaallisia arvoja tulla loukkaamaan. Tämän jälkeen siirrytään itse tarinaan, siihen miten Erik Smeds saatuaan Gorbatshovilta käskyn television välityksellä palaa Suomeen viidenkymmenen vuoden poissaolon jälkeen. Vasta noin viidenkymmenen sivun kuluttua astuu kertoja lukijan eteen.

Du och jag - berättaren och läsaren - befinner oss i centrum av mitt universum: i salen på Smedsas. Läsaren sitter bekvämt i Johannes Smeds gamla gungstol, själva hedersplatsen, centrum av centrum. (EB, 61.)

Sinä ja minä - kertoja ja lukija - olemme minun universumini keskuksessa: Smedsasin salissa. Lukija istuu mukavasti Johannes Smedsin vanhassa kiikkustuolissa, kunniapaikalla, keskuksen keskellä. (EK, 55.)

Asiansa hallitsevana historiantutkijana kertojalla on salin pöydällä tietokone ja arkistointilaatikoita, joihin kertomuksen materiaali on järjestetty. Laatikoihin on päätynyt lehtileikkeitä, haastatteluja ja valokuvia, joita on turha yrittää todentaa. Kun kertoja saa näyttämön kuntoon, voi kertomus sodasta alkaa. Sitä ennen hän kutsuu vainajia:

Som seriös och ansvarsmedveten berättare, mån om att min framställning av Finlands krig skall bli så korrekt och saklig som möjligt, vänder jag mig nu till dem som var med för att söka bistånd. Jag anropar de döda i Siklax. Ni som 
föll i kriget - stig fram ur skuggorna! Kom till mig och berätta hur det var, ni som vet! $(\mathrm{EB}, 69$.)

Vakavamielisenä ja vastuuntuntoisena kertojana, tiukkana siitä että esitykseni Suomen sodasta on niin korrekti ja asiallinen kuin mahdollista, käännyn nyt apua etsien niiden puoleen jotka olivat mukana. Minä kutsun Siklaxin vainajia. Te jotka kaaduitte sodassa - astukaa esiin varjoista. Te jotka tiedätte, tulkaa luokseni ja kertokaa millaista se oli! (EK, 62.)

Samalla tavalla kuin Lanthandlerskans son -teoksessa kehys lomittuu sisäkertomusten kanssa ja kommentoi niitä jatkuvasti. Mitä on ajateltava teoksen aloittavista vainajien kuorosta $^{15}$ ? Kristina Malmio ${ }^{16}$ on myös kiinnittänyt huomiota tähän erikoiseen kehykseen (2005b, 280): "Hur kan gestalterna inleda en berättelse och därefter ge ordet åt berättaren om de en gång existerar inom berättarens berättelse?", "Kuinka henkilöhahmot voivat aloittaa kertomuksen ja sen jälkeen antaa puheenvuoron kertojalle, jos he kerran ovat osa kertojan kertomusta?"(suom. MH.) Mielestäni aloitus korostaa kertojan ja vainajien vastakkaista, jopa kilpailevaa asemaa kertomuksessa (ks. myös Malmio 2005b, 283). Teoksessa Lanthandlerskans son Otto toimii kertojan vastapelurina, esittää vastaväitteitä ja tekee oikeat kysymykset, jotta kertoja pääsee esitelmöimään historiasta ja erityisesti lapuanliikkeestä. Otto toimii myös toisena kertojana, sillä Carl-Johan haluaa kuulla hänen oleskelustaan 1930-luvun Amerikassa, jonne hän pakeni syytettynä murhasta syksyllä 1928. Teoksessa Eriks bok vainajat muodostavat kertojan vastapoolin: he kiistävät kerrotun, keskeyttävät, moittivat kertojaa valheista ja tietysti haluavat kertoa oman versionsa tarinasta. Malmio (2005b, 279) huomauttaa, että vainajien kertomukset perustuvat itse koettuun ja he muodostavat kertomuksen kollektiivisen muistin, kun taas kertoja on kuusikymmenlukulainen rauhanaktivisti, joka tukeutuu kirjallisiin lähteisiin. Hutcheonin $(1988,120,123)$ mielestä yksi postmodernin historiallisen romaanin peruskysymyksiä on se, kenen historia jää eloon, kenen totuus tulee kerrotuksi. Lukija joutuu erilaisten tulkintojen ja mielipiteiden eteen. Kerronta asettaa vastakkain itse koetun, subjektiivisen tiedon ja lähteisiin ja tutkimukseen pohjautuvan, näennäisesti objektiivisen tiedon. Se korostaa kuitenkin historiantutkimuksen vaikeutta: kaikista tutkimuksistaan huolimatta kertoja tekee vääriä johtopäätöksiä. ${ }^{17}$ Lanthandlerskans son -teoksessa kertoja kuulee Otolta totuuden Erikin kuolemasta: sankarikuoleman sijaan Erik teki itsemurhan Tampereen valtauksessa (ks. LS, 224-229; PP, 240-246). "Min berättarauktoritet har blivit ordentligt tillbucklad", "Kertojan auktoriteettiini on tullut paha lommo", toteaa Carl-Johan ja pohtii, mitä syitä Otolla olisi valehdella. Kertojan on vaikea uskoa, että hänen huolelliset selvityksensä eivät ole johtaneet totuuteen.

Kertoja on ollut tekemisissä kuolleiden kanssa aiemminkin. Lanthandlerskans son -teoksessa Carl-Johan vie Oton tapaamaan Vihtori Kosolaa Lapualle. Tällä kertaa kertoja ei tapansa mukaan siirry menneisyyteen vaan herättää Kosolan kuolleista haastateltavaksi. Tulos tosin ei ole järin onnistunut. "Mina resurser är begränsade" (LS, 
181), "Resurssini ovat rajalliset" (PP, 193), joutuu kertoja toteamaan, kun hän esittelee puoliksi mädäntyneen ja haisevan Kosolan. Kertoja onnistuu suututtamaan lapuanliikkeen johtajan kysymyksillään liikkeen väkivaltaisista toimintatavoista, sen suhtautumisesta ruotsinkieliseen väestöön ja Mäntsälän kapinan epäonnistumisesta.

F: Kan det [att upprorsmännen saknade ledning] ha berott på att Lapporörelsens ledning - ni, Vihtori Herttua, Antti Isotalo, prosten Kares, Iivari Koivisto med flera - satt på societetshuset i Helsingfors och söp medan upproret pågick?

K: Perkele! Vet hut, karl! Det var det oförskämdaste... [- - ]

Den döde Lappoledaren snubblar över ett av det omkullvälta kaffebordets ben. Han faller som en nykapad torrfura och slår i golvet med ett blött obehagligt dunsande. (LS, 186-187.)

Kysymys: Saattoiko se [että kapinallisilta puuttui johto] johtua siitä että lapuanliikkeen johto - te, Vihtori Herttua, Antti Isotalo, rovasti Kares, Iivari Koivisto ynnä muut - istui kapinan aikana Helsingin seurahuoneella ryyppäämässä?

Kosola: Perkele! Tietäkää huutia, mies! Tuo oli häpeämättömintä... [- - ] Kuollut lapualaisjohtaja kompastuu kumossa olevan kahvipöydän jalkaan. Hän kaatuu kuin juuri katkaistu kelohonka ja iskeytyy lattiaan kosteasti ja inhottavasti mätkähtäen. (PP, 199.)

Kosolan fyysisen rappion kuvauksella alennetaan sekä hänet itsensä että hänen edustamansa lapuanliike, joka kertojan mukaan omasi fasistisia piirteitä ja oli todellinen uhka Suomen demokratialle (ks. LS, 88, 136, 191, 206, 306; PP, 93, 145, 204, 220, 329).

\section{Monimuotoinen metalepsis}

Genetten $(1990,235)$ mukaan metalepsiksen vaikutus on joko koominen tai fantastinen. Edellisissä esimerkeissä kertojan ja vainajien kohtaamisista se on molempia. Tämän lisäksi kerrontatasojen ja ontologisten tasojen sekoittuminen korostavat teosten yhteiskuntakriittistä asennetta. Colorado Avenuessa jääkärikapteeni Erik Smeds kohtaa Mannerheimin ennen Tampereen valtausta. Kohtauksessa sekoittuvat fiktion todellinen maailma ja unen maailma. Kyseessä on siis Ryanin $(2006,207)$ mainitsema ontologinen metalepsis, jossa kahden eri maailman tasot lomittuvat. Kenraali näyttää Erikille kaatuneita punaisia täynnä olevan ulkorakennuksen. "Finns det någonting värre än ett brödrakrig?” (CA, 249), ”Onko mitään pahempaa kuin veljessota?” (CAV, 244) hän kysyy. Mannerheimin resignoituneet ajatukset sodasta, sen hyödyttömyydestä ja liian kalliiksi tulevasta vapaudesta saavat Erikin raivostumaan, mutta kenraali viittaa häntä vaikenemaan. Mannerheim paljastaa, että joutuu uhraamaan miehiä oman strategisen virheensä vuoksi: Tampere olisi pitänyt vallata aikaisemmin, mutta hän oli arvioinut värin punaisten voimat. Nyt voitto on pakko saada ennen saksalaisten tuloa, jotta se ei näyttäisi pelkästään heidän ansioltaan: "Jag tvingas offra er för politikens skull" (CA, 250), "Minun on pakko uhrata teidät politiikan tähden" (CAV, 247). 
Nej, viskade jägarkaptenen, hans huvud höll på att slås sönder av smärtans släggor, det gnistrade för hans ögon. Nej, nej! [- -]Ni ljuger, ni ljuger! (CA, 250.)

Ei, jääkärikapteeni kuiskasi; hänen päänsä oli haljeta tuskan moukariniskuista, silmissä salamoi. Ei, ei! [- - Te valehtelette, te valehtelette! (CAV, 246.)

Erik on uhrannut ihanteensa puolesta kaiken. Vähän aikaisemmin lukija on tutustunut Erikin idealismia pursuaviin päiväkirjaotteisiin. Kohtauksessa Mannerheimin kanssa voi miltei kuulla, kuinka tuo runebergilainen idealismi ${ }^{18}$ murtuu. Unen maailma muodostaa Genetten (2004, 135-137) mukaan uuden kerrontatason, sillä uni on poikkeama fiktion "todellisuudesta". Kerrontatasot sekoittuvat, kun lukija ei huomaa missä vaiheessa todellinen maailma liukuu unen maailmaan. Mannerheimin ja Erikin kohtaamisessa sekä uneen siirtyminen että siitä havahtuminen ovat lähes huomaamattomia. Tilanne päättyy siihen, että Erik havahtuu itkien lumisesta maasta. Hän ymmärtää, ettei näkisi enää perhettään eikä sovinnolle isän kanssa olisi aikaa. Mannerheim on kyynisyydellään saanut Erikin näkemään sodan mielettömyyden ja omien ihanteidensa kestämättömyyden. Tämä sodanvastainen kohtaus on yksi mieleenpainuvimpia Sundin teoksissa. Ainoastaan Mannerheimin poistuminen tuo hivenen koomisen ja fantastisen sävyn tilanteeseen: "Generalen lade sig elegant på rygg lik en dykare som gör ett baklängeshopp från trampolinen och flög norrut" (CA, 251), "Kenraali asettui elegantisti selälleen kuin sukeltaja, joka hyppää takaperin ponnarilta, ja lensi kohti pohjoista." (CAV, 246.)

Palaan vielä lopuksi Fludernikin jaotteluun. Kirjailijan metalepsis viittaa tilanteeseen, jossa tekijä esiin tulemalla osoittaa, että kyseessä on nimenomaan fiktiivinen tarina. ${ }^{19}$ Kertoja ottaa vastuun tapahtumista ja paljastaa, että hän on keksinyt tarinan eikä vain kerro sitä. (Fludernik 2003, 384.) Sekä Genette että Fludernik käyttävät esimerkkinä Diderot'n teosta Jacques le fataliste et son maître:

Niin, hyvä lukija, mikä minua estäisi sytyttämästä rajua riitaa kolmikon kesken? Jaakko tarttuisi sen tiimellyksessä emäntää hartioista ja paiskaisi hänet ulos huoneesta, isäntä tarttuisi Jaakkoa hartioista ja ajaisi hänet tiehensä [- - . Rauhoittukaa, en minä niin tee. (Diderot 1992, 120.)

Genetten (2004, 26-27) mukaan kyse on lukijan ja kirjailijan sanattoman sopimuksen rikkomisesta. Postmoderni kirjallisuus on hyödyntänyt kirjailijan siirtymistä sisäkertomuksen tasolle hyvin paljon, McHalen mukaan jopa kliseeksi asti. ${ }^{20}$ Kirjailijan ja henkilöhahmojen kohtaaminen kasvokkain on yksi postmodernin kirjallisuuden topos. McHale toteaa osuvasti, että kun modernistinen kirjallisuus häivytti kirjailijan teoksistaan, postmoderni kirjallisuus tuo kirjailijan korostetusti esille, mutta nyt kyseessä ei ole realistisen vaikutelman lisääminen vaan sen murtaminen. (McHale 1987, 199, 213.) García Landa (2004) puhuu sekä kertoja-kirjailijasta (narrador-autor) että 
kirjailija-kertojasta (autor-narrador), mutta toteaa saman tien, ettei näillä ole suurta eroa. Esimerkiksi Diderot'n teoksen kertojahahmo, joka manipuloi niin kertomuksensa henkilöhahmoja kuin lukijaakin, on kirjailija-kertoja. Sundin teosten kertoja on kertoja-kirjailija, joka teoksen fiktiivisessä maailmassa kirjoittaa oman sukunsa historiaa. Kirjailijan metalepsis sopiikin mielestäni parhaiten auktoriaalista kerrontaa ${ }^{21}$ käyttävien romaanien analysoimiseen.

Fludernikin jaottelu selkeyttää metalepsiksen käsitettä, vaikka rajat ryhmien välillä ovatkin häilyviä. Metalepsista on käytetty sekä teoksen realistisuuden että sen konstruktioluonteen korostamiseen. Se on kehittynyt yhä metafiktiivisempaan suuntaan, mutta esimerkiksi Sterne ja Diderot käyttivät sitä jo 1700-luvulla reflektoimaan kerrontaa ja ironisoimaan romaanin konventioita. Metalepsiksen käyttö yhdistää Sundin historialliset romaanit osaksi kirjallista traditiota, jossa aika ajoin havahdutaan kyseenalaistamaan vakiintuneet, kaavamaiset käytänteet ja paljastetaan lukijalle tekstin rakentumistapa. Sundin teoksissa metalepsis korostaa niiden metafiktiivistä luonnetta. Siirtyessään menneisyyteen ja osaksi kertomaansa maailmaa kertoja joutuu vastakkain luomiensa henkilöhahmojen kanssa. Tämä luo lukuisia tilaisuuksia kommentoida niin kerrontatapoja kuin (historiallisen) romaanin konventioita.

Kerrontastrategiana metalepsis yhdistää onnistuneesti kaksi eri aikatasoa: kirjoittamisajankohtaan sijoittuva kehyskertomus antaa kertojalle mahdollisuuden arvioida menneisyyden tapahtumia nykyajasta käsin. Kerrontatasojen välillä edestakaisin liikkuva kertoja yrittää selvittää menneisyyden tapahtumia ja pitää kertomuksen langat käsissään, mutta joutuu usein toteamaan tehtävänsä mahdottomaksi. Sundin teokset osoittavat perinteisen historiantutkimuksen menetelmien riittämättömyyden ja niiden suhtautuminen historiaan onkin kriittisen uudelleenarvioivaa. Metalepsista käyttämällä leikitellään myös kaikkitietävän kertojan konventioilla: kertoja vakoilee omia henkilöitään, kyselee heiltä tietoja tapahtumista ja kutsuu vainajia avukseen saadakseen aikaan asiallisen kertomuksen. Vainajat eivät kuitenkaan ole tyytyväisiä kertojan kevytmieliseen asenteeseen, ja teoksen lopussa he tuovat julki huolensa kertomuksen todenperäisyydestä ja haluavat panna pisteen sille. Kertojan vastaus kuvaa hyvin Sundin historiallisia romaaneja: "Så det är tacken man făr för att man försöker berätta en underhållande historia om i grunden allvarliga ting!" (EB, 510-511), ”Tämä siis on kiitos siitä että yrittää kertoa viihdyttävän tarinan pohjimmiltaan vakavista asioista!" (EK, 439).

\section{Viitteet}

${ }^{1}$ Mika Hallilan $(2004,210)$ mukaan metafiktio on "metapuhetta, joka koskee fiktiota". Myös Outi Oja $(2005,106-107)$ tekee eron tekstin itserefleksiivisyyden ja metafiktiivisyyden välillä. Metafiktio reflektoi nimenomaan omaa fiktiivisyyttään. Sekä Hallila (2004) että Kristina 
Malmio (2005a) ovat pohtineet, mikä on se itse, jota metafiktio reflektoi. "Onko se teksti vai tekstin kirjoittaja vai jokin muu", kysyy Malmio (2005a, 65). Formalistisen näkökulman sijaan Malmio käyttää diskursiivista lähestymistapaa, joka tekstin sijaan kiinnittää huomion kontekstiin ja puhujiin.

${ }^{2}$ Lars Sundin teosten postmodernismia on käsitellyt myös Jussi Ojajärvi (2005, 18-19). Hän mainitsee postmodernistisina piirteinä eri maailmojen tai ontologisten tasojen sekoittumisen, metafiktiivisyyden, historiografisen metafiktion sekä maagisen realismin.

${ }^{3}$ Pariisissa järjestettiin vuonna 2002 La Métalepse aujourd'hui -konferenssi, jossa pidetyt esitelmät on julkaistu teoksessa Métalepses: entorses au pacte de la representation (2005). Gérard Genetten Metalepsis. De la figura a la ficción (2004) ja Monika Fludernikin "Scene shift, metalepsis, and the metaleptic mode" (2003) on esitetty alkuaan konferenssissa.

${ }^{4}$ Genetten mukaan kreikkalainen termi metalepsis saattoi viitata mihin tahansa vaihdokseen, mutta erityisesti termin käyttämiseen toisen sijasta. Myös Marie-Laure Ryan (2006, 206) viittaa kreikkalaiseen alkuperään: meta-etuliite osoittaa ylempää tasoa ja jälkimmäinen osa tulee tarttumista ilmaisevasta verbistä. Hän toteaa: "Metalepsis is a grabbing gesture that reaches across levels and ignores boundaries, bringing to the bottom what belongs to the top or vice versa." Ryan $(2006,205)$ kuvaa kerrontatasoja pyramidimaisena pinona, jossa alimpaan tasoon kuuluvat todellinen kirjailija ja lukija, seuraavalle ekstradiegeettisen tason kertoja ja hänen yleisönsä jne.

${ }^{5}$ Genette viittaa Fontanieriin vain muutamassa alaviitteessä (ks. Genette 1990, 151, 234). Teoksessaan Metalepsis. De la figura a la ficción Genette $(2004,8-13)$ viittaa laajemmin Fontanierin teoksiin sekä César Chesneau Dumarsais'n Traité des tropes -teokseen (1730), jota Fontanier tutkimuksissaan käsittelee.

${ }^{6}$ Ryan viittaa Genetteen retorisen ja Brian McHaleen ontologisen metalepsiksen kohdalla. Ryanin mukaan osa Genetten esimerkeistä on kuitenkin ontologisia ja Genetten Metalepsis. De la figura a la ficción -teoksessaan (2004) tekemä jaottelu figuraaliseen ja fiktiiviseen metalepsikseen vastaa suurin piirtein hänen omaa jaotteluaan retoriseen ja ontologiseen. McHale viittaa Douglas Hofstadterin teoksessaan Gödel, Escher, Bach (1980) esittelemiin termeihin tangled hierarchy (näennäisesti selkeät hierarkkiset tasot sekoittuvat hierarkian rikkoen) ja strange loop (esimerkiksi kun kertomus yllättäen palaa samalle tasolle, mistä alkoi). Trompe-l'œeil on figuuri, jossa lukija huijataan uskomaan olevansa eri tasolla kertomuksessa kuin mitä hän todellisuudessa on (Ryanin mielestä tämä edustaakin retorista metalepsista). (McHale 1987, 115-121; Ryan 2006, 207-209, 218.)

${ }^{7}$ Novellin suomennos on julkaistu Taide-lehdessä 5/1989.

${ }^{8}$ Genette viittaa ekfrasikseen, joka tarkoittaa kuvan, joko todellisen tai kuvitellun, esittämistä sanoin. Tällä tavalla esimerkiksi maalaus tai valokuva voi muodostaa yhden kerrontatason. (Genette 2004, 94-96; 1990, 231.) Sundin teoksissa on runsaasti esimerkkejä ekfrasiksen käytöstä. Esimerkiksi Hannan ja Ed Nessin häkuva ja sen tulkinta (CA, 83; CAV, 77-81), Gustavin muotokuva (LS, 80-82; PP, 84-86), valokuva Senaatintorilta talonpoikaismarssin ajalta (LS, 89-91; PP, 95-97); Charlesin paluu sodasta "Soturin kotiinpaluu" -maalauksen esittämänä (EB, 249-252; EK, 214-217), kuvaus jälleenrakentamisen vuosista taulun "Talkoot Asevelikylässä" avulla (EB, 408-410; EK, 351-353). Kertoja ei pelkästään esitä kuvia vaan vie tarinaa eteenpäin kuvaillessaan tauluja ja valokuvia. Still-kuva elävöitetään, ja kuin huomaamatta kuvailu vaihtuu kerronnaksi (Genette 2004, 103; ks. myös McHale 1987, 117-119). 
${ }^{9}$ Fludernik hylkää tapauksen, jota Genette kutsuu pseudo-diegeettiseksi kerronnaksi. Siinä kehyskertomuksen kertoja astuu sisäkertomuksen kertojan nahkoihin ja kertoo tarinan ikään kuin olisi tämä. Genetten esimerkki on Abbé Prévost'n teoksesta Manon Lescaut (1968). Kertoja välittää Des Grieux'ltä kuulemansa tarinan lukijalle ensimmäisessä persoonassa. Kehyskertomus keskeyttää tarinan vain kerran kahden osan välissä. Fludernikin mielestä tässä ei ole kyseessä todellinen metalepsis, sillä ensimmäisen tason kertojalla on aina mahdollisuus eri tavoin raportoida kuulemansa tarina. (Fludernik 2003, 388.) Olen samaa mieltä Fludernikin kanssa: tässä ei tapahdu metalepsiksen tarkoittamaa kerrontatasojen ylittämistä. ${ }^{10}$ Woody Allen on tarkastellut kerronnan rajojen ylittämistä myös elokuvissaan. The purple rose of Cairo (1985, Kairon purppuraruusu) sijoittuu 1930-luvun lamavuosiin. Mia Farrow esittää tarjoilijana työskentelevää Ceciliaa, jolla on väkivaltainen aviomies. Ankeaa arkielämäänsä Cecilia pakenee elokuviin. Eräänä iltana hänen suosikkielokuvansa sankari astuu valkokankaalta elokuvasaliin puhuttelemaan häntä, ja he rakastuvat. Pääähden tempaukset hätkähdyttävät paitsi realistista maailmaa, myös elokuvan sisäistä maailmaa. Myös Genette $(2004,70)$ mainitsee tämän elokuvaan. Hän muistuttaa, että vaikka toinen tasoista onkin elokuvassa "todellinen", tapaus on mahdollinen vain fiktiivisessä maailmassa.

${ }^{11}$ Siirtymää ilmaisevia fraaseja käytettiin jo varhaisella keskiajalla. Fludernikin mielestä tällainen makrotason rakenne tuli tarpeelliseksi, kun aiemmin suullisesti välitetyt tarinat siirrettiin kirjalliseen muotoon. Myöhemmin tilalle tuli sillä aikaa kun -fraasi. Siirtymäfraasin katoamiseen vaikutti tekstin jakaminen lukuihin, joiden alusta muodostui luonnollisia siirtymäkohtia näyttämöltä toiselle. Mahdollisesti myös ensimmäisen persoonan yleistyminen kerronnassa vaikutti fraasin käytön vähenemiseen, onhan minäkertoja pääsäntöisesti läsnä kaikissa tilanteissa. (Fludernik 2003, 389-390.)

${ }^{12}$ Fludernikin mukaan retorinen metalepsis on saanut alkunsa kertojan metalepsiksesta, jota käytettiin tilanteesta toiseen siirtymiseen. Kehitys on ollut seuraavanlainen: siirtyminen $A$ : sta B:hen $\rightarrow>$ paluu B:hen $\rightarrow>$ takauma $\rightarrow$ kerronnallinen kommentti. Vähitellen näyttämön vaihdosta ilmaisevat jättäkäämme tai siirtykäämme väistyvät paluuta ilmaisevien fraasien tieltä. Siirtymästä tulee usein selittävä takauma, joka muodostaa tauon kerrontaan. Tauko puolestaan antaa kertojalle mahdollisuuden tarjota taustatietoja lukijalle. Retorinen metalepsis muodostaa puuttuvan linkin takauman ja metafiktiivisesti käytetyn narratiivisen kommentin välille. (Fludernik 2003, 390-391.)

${ }^{13}$ Ojajärvi $(2005$, 39-44) on käsitellyt Sundin teosten kuoleman symboliikkaa, sitä miten kertominen rinnastuu elämään (vertauskuvana talon rakentaminen tai entisöinti) ja vaikeneminen ja unohtaminen kuolemaan (vertauskuvana talon purkaminen). (Kertomisen rinnastamisesta elämään ks. myös McHale 1987, 228-231.) Entisöinti on Sundilla myös vertauskuva historiankirjoittamisen vaikeudesta: "Varje renovering blir ofelbart en rekonstruktion. Den kan visa större eller mindre trohet mot originalet, men likafullt måste nytt virke begagnas för att lappa igen hålen efter det som är sönderruttnat och oåterkalleligen försvunnet. Det gäller gamla villor i skärgården, likaväl som berättelser. (LS, 249-250), "Entisöimisen tulos on aina väistämättä rekonstruktio. Se voi olla enemmän tai vähemmän uskollinen alkuperäiselle, mutta uutta puuta on yhtä kaikki käytettävä niiden aukkojen paikkaamiseen, jotka ovat syntyneet lahonneen ja iäksi kadonneen tilalle. Se koskee vanhoja saaristohuviloita yhtä hyvin kuin kertomuksiakin.” (PP, 269.)

${ }^{14}$ Hutcheonin väitettä metafiktion epäpoliittisuudesta on kritisoinut muun muassa Hallila $(2005,77)$. McHale $(1987,179-196)$ on analysoinut joitakin teoksia, joita Hutcheon 
pitää pelkästään äärimodernistisina. McHale pitää esim. Raymond Federmanin ja Ronald Suckenikin teoksia postmodernismiin kuuluvina ja löytää niistä myös poliittista sanomaa, vaikka Suckenik itse on todennut, että postmoderni kirjallisuus käsittelee vain kielen ja kirjallisuuden ongelmia, ei poliittisia tai yhteiskunnallisia (Suckenick 1976; ks. Saariluoma 1992, 24).

${ }^{15}$ Malmio (2005b, 279) vertaa osuvasti teoksen vainajia antiikin kuoroon. Lanthandlerskans son teoksen lopussa kertoja kutsuu Hannan kauppapuodin penkillä istuvia ukkoja sanoilla "denna min berättelses sträva kör" (LS, 423), "tämän kertomukseni karheaääninen kuoro" (PP, 456).

${ }^{16}$ Malmio (2005b, 284) käsittelee Sundin teosta Stephen Greenblattin sosiaalista energiaa koskevan teorian avulla. Kerrontatasojen ylittäminen ja rajan ylittäminen kuolleiden ja elävien välillä herättävät lukijassa erilaisia tunteita: tyytyväisyyttä, iloa, ahdistusta. Kerronnan itsetietoinen siirtyminen edestakaisin totuuden ja valheen, fiktion ja todellisuuden, elävien ja kuolleiden välillä ja siihen liittyvä jatkuva rajojen ylittäminen pohjustaa tekstin intensiteetin ja kiehtovuuden eli sen sosiaalisen energian, kyvyn herättää lukijan tunteet.

${ }^{17}$ Sundin teoksista löytyy useita esimerkkejä siitä, kuinka huhu tai väärä tieto muuttuu dokumentteihin kirjatuksi totuudeksi. Teoksessa Eriks bok kertoja selostaa yksityiskohtaisesti, kuinka tieto Charlesin kuuroudesta muuttuu matkalla, niin että lopulta vanhemmille viedään surusanoma Charlesin kuolemasta (ks. EB 201-209, 216-231, 249-252, EK, 173-180, 186-199, 214-217.)

${ }^{18}$ Kertoja kuvaa, kuinka Erik lapsena ihailee J. L. Runebergin Fänrik Ståls sägner (1848, 1860, Vänrikki Stoolin tarinat 1889) teoksen sankareita. Hän osaa tarinat ulkoa ja ne muodostavat pohjan leikeille. (CA, 171, 195; CAV, 167, 190.). Saranpa (1998, 276-277) on kiinnittänyt huomiota Erikin hahmon anakronistisuuteen. Hän huomauttaa, kuinka Erikin ja Mannerheimin tapaamisessa törmäävät kaksi eri vuosisataa ja ajatusmaailmaa: Runebergin idealistinen, sankaruutta ihannoiva 1800-luku ja Mannerheimin käytännöllinen 1900-luku. ${ }^{19}$ Genette keskittyy teoksissaan pääasiassa kirjailijan metalepsikseen. Hän antaa runsaasti esimerkkejä kirjallisuudesta, teatterista, televisiosta ja elokuvista. Elokuva, joka kuvaa elokuvan tekemistä, tai maalaus, jonka sisällä on toinen maalaus, tuovat usein myös tekijänsä esiin. (Genette 2004, 76-80, 92-94.) Genetten esimerkeistä osa sopisi paremmin Fludernikin jaottelun muihin kategorioihin, sillä useissa niistä on kyse kertojan tai lukijan siirtymisestä tarinaan. Genetten käsitykseen kirjailijan metalepsiksesta on ehkä vaikuttanut se, että hän hylkää sisäistekijän ja sisäislukijan käsitteet - kerrontatapahtumaan tulee liikaa väkeä. Hän perustelee näkemystään osoittamalla lukuisin esimerkein, että lähes aina voimme puhua todellisesta kirjailijasta. Hän ei myöskään näe mitään syytä päästää tekijää ideologisesta (tai muustakaan) vastuusta. (Genette 1988, 139-145.) Muun muassa Nelles (1997, 34-43.) kritisoi Genetteä. Hän käy yksitellen läpi Genetten antamat esimerkit ja päätyy päinvastaiseen näkemykseen.

${ }^{20}$ Vaikka kirjailija ilmestyy tarinaan, kyse on aina fiktiivisestä henkilöstä. Ontologinen raja kirjailijan ja fiktiivisen teoksen maailman välillä on ylittämätön. (McHale 1987, 215.)

${ }^{21}$ Esimerkkiteoksina auktoriaalisesta kerronnasta mainitaan useimmiten Denis Diderot'n Jacques le fataliste et son maître (1773, Jaakko fatalisti ja hänen isäntänsä 1992), Laurence Sternen The Life and Opinions of Tristram Shandy, gentleman (1759-1767, Tristram Shandy: elämä ja mielipiteet, 1998) sekä Henry Fieldingin teokset The History of the Adventures of Joseph Andrews and his Friend, Mr. Abraham Abrams (1742, Joseph Andrewsin seikkailut ja 
The History of Tom Jones, a Foundling (1749, Tom Jones 1994). Hosiaisluoman (2003, 78) mukaan "auktoriaalisessa kerronnassa kertoja kommentoi tapahtumia ja saattaa puhutella henkilöhahmoja, mutta ei osallistu kertomiinsa tapahtumiin”.

\section{Lähteet}

\section{Lähdeteokset}

CA = Sund, Lars 1991: Colorado Avenue. Helsingfors: Söderström.

CAV = Sund, Lars 1992: Colorado Avenue. Suom. Kaarina Ripatti. Porvoo - Helsinki - Juva: WSOY.

LS = Sund, Lars 1997: Lanthandlerskans son. Stockholm: Rabén Prisma.

PP = Sund, Lars 1998: Puodinpitäjän poika. Lanthandlerskans son. Suom. Kaarina Sonck. Porvoo - Helsinki - Juva: WSOY.

$\mathrm{EB}=$ Sund, Lars 2003: Eriks bok. Helsingfors: Söderström.

EK = Sund, Lars 2004: Erikin kirja. Eriks bok. Suom. Liisa Ryömä. Porvoo - Helsinki - Juva: WSOY.

\section{Kaunokirjallisuus}

Allen, Woody I98 I: Sivuvaikutuksia. Side effects. Suom. Seppo Loponen. Helsinki: Kirjayhtymä.

DIDEROT, DENIS I992/I 773: Jaakko fatalisti ja hänen isäntänsä. Jacques le fataliste et son maître. Suom. Jukka Mannerkorpi. Porvoo - Helsinki - Juva: WSOY.

Sterne, Laurence 1998/1759-1767: Tristram Shandy: elämä ja mielipiteet. The Life and Opinions of Tristram Shandy, gentleman. Suom. Kersti Juva. Porvoo - Helsinki - Juva: WSOY.

TOPELIUS, ZACHARIAS I923/I85 I-I 866: Fältskärns berättelser. Fjärde cykeln, II. Helsingfors: Holger Schildts Förlagsaktiebolag.

TOPELIUS, z. I 998/ I 888: Välskärin kertomuksia 3. Suom. Juhani Aho. Porvoo - Helsinki - Juva: WSOY.

\section{Tutkimuskirjallisuus}

CULLER, JONATHAN 2004: Omniscience. Narrative 1/2004, vol. 12. 22-34.

FLudernik, Monika 2003: Scene Shift, Metalepsis, and the Metaleptic Mode. Style 4/2003, vol. 37. 382-400.

GARCÍA LANDA, JOSÉ ÁNGEL 2004/I996: Nivel narrativo, status, persona y tipología de las narraciones. http://www.unizar.es/departamentos/filologia_inglesa/garciala/publicaciones/nivel.html . Viitattu 10.3.2007. Julkaistu myös: Miscelánea: A Journal of English and American Studies 17/1996. 91-121.

GENETTE, GÉRARD 2004: Metalepsis. De la figura a la ficción. Métalepse. De la figure à la 
fiction. Trad. Luciano Padilla López. Serie Breves. [Buenos Aires]: Fondo de Cultura Económica.

GENETTE, GÉRARD I990/I980: Narrative discourse: an essay in method. Discours du reicit. (Figures III, 1972). Translated by Jane E. Lewin. Ithaca (N.Y.): Cornell University Press.

GENETTE, GÉRARD 1988/1983: Narrative discourse revisited. Nouveau discours du récit. Ithaca (N.Y.): Cornell University Press.

HALLILA, MIKA 2005: Kuinka realismi kielletään? Metafiktio ja romaanin todellisuusilluusiot. Kirjallisuudentutkimuksen aikakauslehti Avain 1/2005. 71-78.

HALLILA, MIKA 2004: Mitä metafiktio reflektoi? Metafiktio ja sen suhde romaanin traditioon. Katkos ja kytkös. Modernismin ja postmodernismin subde traditioon. Toim. Katriina Kajannes, Leena Kirstinä, Annika Waenerberg. Suomalaisen Kirjallisuuden Seuran toimituksia 966. Helsinki: Suomalaisen Kirjallisuuden Seura. 207-219.

hutcheon, LINDA I988: A Poetics of Postmodernism. History, theory, fiction. New York - London: Routledge.

HOSIAISLUOMA, YRJÖ 2003: Kirjallisuuden sanakirja. Helsinki: WSOY.

MALMIO, KRISTINA 2005A: Katse peiliin ja peilin taakse - muutamia kysymyksiä ja näkökulmia kirjallisuuden metatasojen tutkimukseen. Kirjallisuudentutkimuksen aikakauslehti Avain 1/2005. 59-70.

MALMIO, KRISTINA 2005B: Att tala med de döda. Metafiktivitet och social energi i Lars Sunds Eriks bok. Det öppna rummet. Festskrift till Merete Mazzarella den 4 februari 2005. Helsingfors: Söderström. 277-287.

MCHALE, BRIAN I987: Postmodernist fiction. New York: Methuen.

NELles, william I997: Frameworks: Narrative Levels and Embedded Narrative. American university studies. Series XIX, General literature, vol. 33. New York: Peter Lang.

OJA, OUTI 2005: Vielä 1716 sanaa kirjallisuuden metatasoista. Kirjallisuudentutkimuksen aikakauslehti Avain 3-4/2005. 104-108.

OJAJÄRVI, JUSSI 2005: Leikki, historia ja kuolema - Lars Sundin Lanthandlerskans sonin postmodernismi. PoMon tila. Kirjoituksia kirjallisuuden postmodernismista. Toim. Anna Helle ja Katriina Kajannes. Jyväskylä: Kampus Kustannus. 17-55.

RYAN, MARIE-Laure 2006: Avatars of Story. Electronic Mediations, Volume 17. Minneapolis/London: University of Minnesota Press.

SAARILUOMA, LIISA I992: Postindividualistinen romaani. Helsinki: Suomalaisen Kirjallisuuden Seura.

Saranpa, Kathy i 998: Att leka med historien.Lars Sunds Colorado Avenue. Historiska och litteraturhistoriska studier 73. Helsingfors: Svenska Litteratursällskapet i Finland. Utgivna genom John Strömberg. 269-279.

TAMMI, PEKKA I 992: Kertova teksti. Esseitä narratologiasta. Helsinki: Gaudeamus. 